\title{
Строительство
}

\section{Производство бетонных смесей с применением противоморозных добавок «КРИОПЛАСТ СП25-2» и «КРИОПЛАСТ ЭКТРА»}

\author{
Бурик С.В., студент, \\ Технический институт (филиал) \\ Северо-Восточного федерального университета, \\ 2. Нерюнгри \\ E-mail: buriks@list.ru
}

Научный руководитель: стариий преподаватель Кулигина Е.С.

Большую часть года температура воздуха в нашем районе колеблется на отметке ниже нуля градусов Цельсия (средняя температура за период октябрь-апрель $-23.2^{\circ} \mathrm{C}$ ). Такие погодные условия не позволяют продолжать строительство в условиях отрицательных температур в том же темпе, что и в теплый период, а то и вовсе заставляют приостановить некоторые этапы строительства.

Бетон при отрицательных температурах замерзает, не набрав при этом критическую прочность, из-за того, что вода замерзает, и ее кристаллы разрывают внутренние связи и, разрушая структуру, полностью лишают прочности. Другими словами, не успев затвердеть, бетонная смесь замерзает.

Чтобы избежать таких неудобств, применяются два способа. Можно обеспечить обогрев бетонного сооружения до того момента, когда наберется необходимая прочность, а можно предотвратить процесс охлаждения воды, добавив в раствор противоморозные добавки. Противоморозные добавки дают возможность продолжать работу с бетонными смесями даже при температуре до 25 градусов ниже нуля.

Добавка предотвращает замерзание воды в смеси бетона во время транспортировки и до момента начала гидратации цемента. Это обеспечивает процесс гидратации - полного вступления в реакцию с цементом. В соответствии с требованиями ГОСТ 24211-91 «Добавки для бетонов. Общие технические требования», использование противоморозных добавок в бетон рекомендуется при температуре от 0 до -25 градусов по Цельсию.

В данной работе рассмотрены бетонные смеси с применением противоморозных добавок «КРИОПЛАСТ СП25-2» и «КРИОПЛАСТ ЭКТРА». Производитель данных добавок гарантирует производство бетонных работ до температуры наружного воздуха $-25^{\circ} \mathrm{C}$. Эти противоморозные добавки исследуются по заказу ООО ПСК «РОСТ» («КРИОПЛАСТ ЭКТРА») и ООО «Строим сами» («КРИОПЛАСТ СП25-2»).

Целью данной работы является определение возможности практического использования данных противоморозных добавок при отрицательных температурах в нашем регионе.

Ход эксперимента

За основу был взят состав бетона В25. На замес бетона объемом 15 литров расход материала составил:

Цемент-7.5 кг 
Песок-8.55 кг

Щебень-16.5 кг

Воды-3.6 л

В качестве заполнителей были использованы материалы:

песок - отсев дробления фракции 0-5 мм,

щебень - алданский, фракции 5-20 мм, марка по дробимости 1200.

Было изготовлено три замеса. В составе №1 была применена пластифицирующая добавка «Кратасол-ПФМ» в количестве $0.6 \%$ от массы цемента. Этот состав был принят как контрольный. Состав №2 был изготовлен с использованием жидкой противоморозной добавки «Криопласт СП25-2» из расчета 5\% от массы цемента (рекомендация технических условий на эту добавку). Состав №3 изготовлен с использованием сухой противоморозной добавкой «Криопласт Экстра», добавка составила $0.5 \%$ от массы цемента (рекомендация технических условий на эту добавку).

Всего было изготовлено по 12 образцов каждого состава.

Половина образцов контрольного состава была выставлена на мороз (температура воздуха - $15^{\circ} \mathrm{C}$ ). Вторая половина поставлена в камеру нормального твердения в соответствии с требованиями ГОСТ 10180-2012 «Бетоны. Методы определения прочности по контрольным образцам» пункт 4.3.2. В дальнейшем 2 образца, которые находились на морозе, и 2 образца из камеры нормального твердения испытаны в возрасте 3 суток. Затем, в возрасте 7 и 14 суток также были испытаны по 2 образца, находящихся на морозе и в камере нормального твердения.

Составы №2 и №3, содержащие противоморозные добавки, были распределены одинаковым способом: были выставлены по 2 образца на 3, 7, 14 и 28 суток на мороз (15 градусов Цельсия). Затем эти образцы были также испытаны (3 суток, 7 суток, 14 суток).

Так как проверялась способность противоморозных добавок снижать температуру замерзания бетонной смеси при низких температурах, не было необходимости оставлять образцы составов №2 и №3 в нормальных условиях твердения.

Полученные данные показаны в виде таблицы.

\begin{tabular}{|c|c|c|c|c|c|c|c|c|c|c|}
\hline \multirow{3}{*}{ 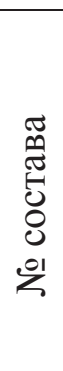 } & \multirow{3}{*}{ 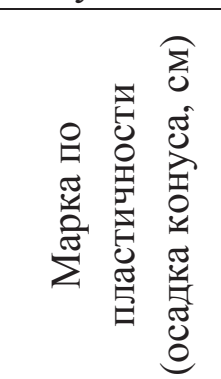 } & \multirow{3}{*}{ 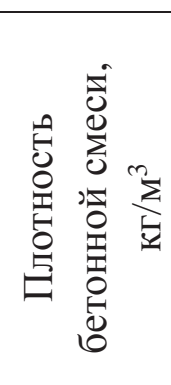 } & \multirow{3}{*}{ 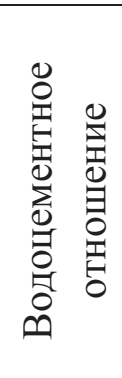 } & \multicolumn{6}{|c|}{$\mathrm{R}_{\text {сжатия, кг } / \mathrm{cm}^{2} \text {, в возрасте, суток }}$} & \multirow{3}{*}{ Прим. } \\
\hline & & & & \multicolumn{2}{|c|}{3} & \multicolumn{2}{|c|}{7} & \multicolumn{2}{|c|}{14} & \\
\hline & & & & $\stackrel{n}{\stackrel{n}{\mid c}}$ & $\begin{array}{l}\text { U } \\
\text { ํㅡㄴ } \\
\rightarrow\end{array}$ & $\stackrel{\infty}{\mathcal{H}}$ & $\begin{array}{l}0 \\
\stackrel{0}{\circ} \\
\stackrel{1}{1}\end{array}$ & $\stackrel{\oplus}{\mathcal{P}}$ & $\begin{array}{l}0 \\
0 \\
0 \\
+1\end{array}$ & \\
\hline 1 & $\Pi 2(4-7 \mathrm{~cm})$ & 2,480 & 0,467 & 294 & 3,6 & 384 & 26 & 485 & 27 & \\
\hline 2 & П2 (6-7 см) & 2,500 & 0,424 & & 6 & & 32 & & 36 & \\
\hline 3 & $\Pi 2(7-8 \mathrm{~cm})$ & 2,480 & 0,48 & & 2,45 & & 18 & & 17 & \\
\hline
\end{tabular}

Из таблицы видно, что набор прочности после 7 суток практически прекратился, но к 14 суткам вода еще находится в жидкой фазе. Однако, для предотвращения замерзания бетона в дальнейшем все же необходим дополнительный прогрев. 
В таблице не указаны данные по прочности бетона после выдержки бетонных образцов при температуре $-10^{\circ} \mathrm{C}$ в возрасте 28 суток, так как эксперимент еще продолжается.

В ходе эксперимента выявлен неожиданный результат. Добавка «Кратасол ПФМ», введенная в состав №1, оказывает такое же влияние на бетон как противоморозная добавка, позволяя бетону набирать прочность в условиях отрицательных температур. «Кратасол - ПФМ» - полифункциональная добавка для бетонов, соответствует требованиям ГОСТ 24211-91 «Добавки для бетонов. Общие технические требования»и относится к группе суперпластификаторов и добавкам, повышающим морозостойкость, но не снижающих температуру замерзания.

Как было сказано выше, эксперимент еще не закончен. Следующая цель узнать, на сколько процентов изменится прочность бетона после выдерживания на морозе без прогрева в течении 28 суток по сравнению с прочностью бетонных образцов, выдержанных 28 суток в камере нормального твердения. Еще один этап этой работы является определение потери прочности бетонных образцов после выдерживания их в течении 28 суток на морозе, а затем в нормальных условиях твердения 28 суток, по сравнению с проектной маркой бетона.

Однако можно сделать предварительные выводы: противоморозные добавки «КРИОПЛАСТ СП25-2» и «КРИОПЛАСТ ЭКТРА» действительно не дают бетонным смесям замерзнуть при низких температурах и позволяют набирать прочность до устройства дополнительного прогрева как и указано в технических характеристиках на эти добавки, то есть данные добавки можно использовать на практике.

Список литературы:

1. ГОСТ 10180-2012 «Бетоны. Методы определения прочности по контрольным образцам»

2. ГОСТ 24211-91 «Добавки для бетонов. Общие технические требования».

\section{Слесарный молоток с механизмом вторичного удара}

Дегтярев А.В., студент, Северо-Восточный федеральный университет, 2. Якутск E-mail: aytal14031998@gmail.com

Научный руководитель: стариий преподаватель, магистр-инженер Анисимов E.E.

Целью данной работы является усовершенствование слесарного молотка с механизмом вторичного удара для уменьшения отскока и увеличения ударной силы. Для решения поставленной задачи необходимо было решить следующие задачи:

1. Изучить виды столярных и слесарных молотков;

2. Разработать конструкцию молотка со вторичным ударом и изготовить молоток; 